\title{
Sağlık Turizminin Geliştirilmesinde Sağlık Bakanlıklarının Koordinatör Kuruluşları: Türkiye, Malezya ve Güney Kore Karşılaştırması
}

\section{Coordinator Organizations of the Ministries of Health in the Development of Health Tourism: Comparison of} Turkey, Malaysia, and South Korea

\section{Salih Kenan ŞAHIN ${ }^{1}$}

\section{ÖZ}

Dünya'da önemi giderek artan, yılın 12 ayı boyunca devam edebilen ve katma değeri en yüksek turizm çeşitlerinden biri olan sağlık turizmi, ülkemizin de öncelikli gündem başlıklarından biridir. Sağlık turizmi alanında küresel rekabet üstünlüğü elde etmiş ülkelerin birçoğunda koordinatör kuruluş niteliğinde Bakanlıklara bağlı olarak çeşitli misyonlara sahip organizasyonlar oluşturulmuştur. $\mathrm{Bu}$ çalışmada Türkiye ile Malezya ve Güney Kore'nin benzer amaç, hedef ve vizyona sahip olan sağlık turizmi koordinatör kuruluşlarının karşılaştırılması amaçlanmıştır. Çalışma derleme niteliğindedir. Türkiye son 10 yılda özel sektörün liderliğinde medikal turizm başlığında önemli başarılar ortaya koymuştur. Devletin çeşitli başlıklarda destekleriyle medikal turizm de elde edilen başarının geliştirilmesi ve diğer sağlık turizmi kollarında da benzer başarının sergilenmesi amacıyla kurulan Uluslararası Sağlık Hizmetleri A.Ş., diğer ülke örnekleriyle de rekabet ve iş birliğini beraber yürütmeli ve başarılı uyguları ülkemizde de hayata geçirmelidir. $\mathrm{Bu}$ amaca hizmet edecek şekilde esas lokomotif gücü oluşturan özel sağlık sektörü ve acentelerin etkili desteklenmesi pazar liderliği hedefine ulaştırabilecektir. Bunun için sağlık sektörünün tüm paydaşları ile koordineli çalıșmalar yürütülmeli, mevzuatların uluslararası geçerliliğinin sağlanması, farklı pazarlar için farklı pazarlama stratejilerinin geliştirilmesi, yurt dişında kurulacak irtibat ofisleri ile tanıtım faaliyetlerinin daha aktif bir şekilde yürütülmesi, farklı dillerde alınan veya alınması planlanan hizmetlerle ilgili kapsamlı bilgi paylaşımının yapılması, proje destekleri ve medya ödülleri ile teşviklerin yapılması gibi faaliyetler ile başarıya ulaşmak mümkün olacaktır.

Anahtar Kelimeler: Sağlık turizmi, Sağlık turisti, Turizm

\section{ABSTRACT}

Health tourism, which is one of the types of tourism with the highest added value and that can continue for 12 months in the world, is one of the priority agenda topics of our country. In most of the countries that have gained a global competitive advantage in the field of health tourism, organizations with various missions have been established under the coordinator of the Health Ministries. In this study, the medical tourism with Turkey, Malaysia and South Korea aimed to compare the coordinator organizations which have similar goals, objectives, and visions. The study is a collected work. Turkey's private sector leadership in the last 10 years has demonstrated remarkable success in medical tourism title. Established with the support of the government in various headings to improve the success achieved in medical tourism and to demonstrate similar success in other health tourism branches, International Healthcare Services Incorporated Company. It should carry out competition and cooperation with other country examples and implement successful practices in our country. To serve this purpose, effective support of the private health sector and agencies, which constitute the main driving force, will be able to reach the target of market leadership. It will be possible to achieve success thanks to carrying out coordinated studies with all stakeholders of the health sector, ensuring the international validity of the legislation, developing different marketing strategies for different markets, conducting promotional activities more actively with liaison offices to be established abroad, sharing comprehensive information about services received or planned to be received in different languages, project supports and media awards and incentives.

Keywords: Health tourism, Health tourist, Tourism

\footnotetext{
1 Dr., Salih Kenan ŞAHIN, Sağlık Yönetimi, İstanbul Medipol Üniversitesi Sağlık Bilimleri Enstitüsü Sağlık Yönetimi, drsalihkenan@ gmail.com, ORCID: 0000-0002-8308-8188 
Sağlık hizmeti talebini kişilerin ikamet ettikleri yerden farklı olarak başka konumlara özellikle sicak iklime sahip yerlere seyahatte bulunması geçmiş dönemlerde görülen bir olgudur. Günümüzde ise söz konusu hareketliliklerin yönünde ve kapsamında esaslı değişimler yaşanmaktadır. İlk zamanlarda gelişen ülkelerden gelen hastalar sağlık sisteminin güçlü olduğu gelişmiş ülkelere yönelirken, özellikle son on yılda bu tablo genellikle gelişmekte olan ülkelere evrilmiştir. ${ }^{1}$ Dünyanın küreselleşmesi ile ülkeler arasında oluşan iş birliğinin, bireylerin ulaşım özgürlüklerinin ve seyahat kolaylıklarının artmasıyla birlikte, dünyanın çeşitli ülkelerinde kaliteli sağlık hizmeti arzı için yeni firsatların gelişmesi, sağlığın sunumundaki finansmanının hem ülkeler hem de bireyler için problem teşkil etmesi sağlık turizminin tüm dünyada gelişmesine olanak sağlamıştır. ${ }^{2}$

Sağllk turizmi, hastaların acil sağllk hizmetini ya da seçtikleri bir sağlık hizmetini farklı ülkelerden alması olarak tanımlanabilir. Daha geniş bir tanımlama ile Sağlık Bakanlığı Sağlık Turizmi Koordinasyon Kurulu sağl1k turizmini; "bireylerin hem koruyucu hem tedavi edici hem rehabilite edici hem de sağlığl geliştirici hizmetleri almak amacı ile yaşadıkları ülke dışındaki bir ülkeye ziyaretleridir" ş̧eklinde ifade etmiştir. ${ }^{3}$ Sağlık turizmi ülkelerin ekonomisine ilişkili ve paydaşı olduğu tüm sektörlerle birlikte yüksek katma değer sağlama potansiyeline sahiptir. Yilın her mevsiminde gerçekleşme imkanının olması da ayrıca önemlidir. $\mathrm{Bu}$ sebeplerden ötürü sağlık turizmi faaliyetlerini olumsuz yönde etkileyecek her türlü düzeltmelerin (hukuki altyap1 vb.) zaman kaybetmeksizin yapılmas gerekir. ${ }^{4}$ Sağllk turizminin finansal getirileri, sağlık kaynaklarının gelişimi için aracı olarak kullanılabilir. Bu sayede sağlık sistemi güçlü kılınabilir. ${ }^{1}$

Sağlik turizmi faaliyetleri ülkeden ülkeye farklılık gösteren faktörlere sahiptir. $\mathrm{Bu}$ faktörler çeşitli çalışmalar tarafından sentezlenerek ortak bir paydada toplanmıştır. $\mathrm{Bu}$ doğrultuda, sağlık turistlerinin tercihlerini

\section{GİRIS}

etkileyen faktörler arasında; ülkenin politik ve sosyoekonomik durumları, mevzuat ve diğer turizm hizmet faktörleri, arac1 kuruluşlar konum ve faaliyetleri yer almaktadır. ${ }^{5}$ Bunların yanında, teknolojinin gelişmesiyle tedavileri kaliteli yapan ve hasta güvenliğini en üst seviyede tutan ülkelerin varlığı, sağlı hizmetleri maliyetlerinin artması, ulaşım hizmetlerinin gelişmesi, bireylerdeki kültürel gelişim ve yeni yerler gezme istekliliğinin artması gibi konuların da sağlık turizmine olan talebi arttırdığ 1 vurgulanmaktadır. ${ }^{6}$

Ülkelere, bölgelere ve sağl1k hizmeti talep eden bireylerin özelliklerine göre değișiklik gösteren koşullar genel olarak aşağıdaki gibi özetlenebilir; ${ }^{7}$

- Sağlı sistemlerinin ülkeden ülkeye değişiklik göstermesi

- Döviz kuru farklılıkları

Ekonomi ve gelir düzeyi farklılıkları

Sosyal, teknolojik, politik, kültürel, dinsel farkl111klar

Verilen sağlık hizmetiyle hasta tatmini arasındaki ilișkiler

- Verilen hizmet kalitesi ve hizmetin maliyeti

Dil farklılıkları veya benzerlikleri

Hasta güvenliğine verilen önem

Malpraktis uygulamaları konusunda yetersiz yasalar

- Akredite olmuş hastane sayısındaki artışlar.

Sağlık turizmi, bireyler için daha kaliteli sağlık hizmetini, daha hızlı ve daha ekonomik fiyata erişme imkânı sunmaktadır. Öte yandan sağlık profesyonellerinin istihdam, kariyer ve vaka deneyim firsatları sunmaktadır. Sağlikta küresel marka ülke olma yolunda küresel marka hekimlerin oluşması da sağlık turizminin sağladıklarındandır. Sağlık hizmet sunum standartlarının gelişmesi, kalitenin artması, fiziki ve teknolojik gelişimde sağlık turizminin sağlık sektörüne katkılarıdır. Sağlık ile ilgili yeni yatırım alanlarının oluşması ise milli gelire ve sağlık ekonomisine katkısı da en önemli sonuçlarındandır. 
Bu çalışmada Türkiye'nin sağlık turizmi potansiyelinin en iyi şekilde değerlendirilebilmesi için başarılı rakiplerinin bu alandaki örgütlenmelerini ve politikalarını değerlendirebilmek adına Uluslararası Sağlık Hizmetleri A.Ş. (USHAŞ) ile benzer statü, amaç ve hedeflere sahip, sağlık turizmi koordinatör kuruluşları olarak nitelendirilen Malezya Sağlık Seyahat Konseyi (Malezya Healthcare Travel Council- MHTC) ve Kore Sağlık ve Endüstrisi Geliştirme ve Enstitüsü'nün (Korea Health Industry Development Institute- KHIDI) karşılaştırılması amaçlanmıştır. Çalışma derleme niteliğindedir.

\section{Sağlık Turizmi ve Türkiye}

Sağlık turizminde küresel rekabet savaşı her geçen gün artmakta ve ülkeler bu rekabet ortamında üstünlük sağlayabilmek için çeşitli stratejiler geliştirmektedir. Türkiye "Sağlıkta Dönüşüm Programı"nın sağladığı ivme ile kat ettiği gelişmeler sayesinde küresel sağlık turizmi pastasından daha fazla pay almaya başlamış; sağlık turizminde güçlü olan ülkeler (Hindistan, Tayland, Malezya, Macaristan, Singapur, Güney Kore) ile rekabet etmeye başlamıştır. Son dönemde devlet destekli yatırımlar ile genel turizm destinasyonlarındaki ulusal sağlık hizmetlerinin kalitesi de artmıştır. ${ }^{8}$

Türkiye'nin coğrafi konumu, sahip olduğu teknolojik altyapı ve kalifiye sağlık personelleri ile gelişmiş ülkelerinin standartlarında sağlık hizmeti sunması, bunun yanında fiyat avantajının da olması, bekleme sürelerinin ortalamasının diğer

ülkelere göre daha kısa olması, JCI tarafından akredite edilen sağlık kuruluşlarının sayısı bakımından ABD'den sonra dünyada ikinci sırada yer alması, genç iş gücünün varlığg, sağlık turizmiyle entegre edilebilecek yüksek kalitede farklı turizm olanaklarının bulunması (inanç, kültür vb.) sağlık turizmi konusunda yer alan avantajlarımız olarak sinıflandırılabilir. Bunların yanı sıra son yıllarda dünya çapında ses getiren başarılı organ nakillerinin yapılması ve sağlık turizminin ulusal stratejik planlar arasında yer alması Türkiye'nin potansiyeline ulaşma noktasında ayrıca itici güçtür. ${ }^{9-15}$ Yakın uçuş mesafesi, uygun tedavi ücretleri, hizmet kalitesi, son teknoloji ile donanmış hastaneler, bekleme sürelerinin az olması, sosyal dokudaki benzerlikler ve cazip gelen turistik faaliyetler hasta hareketliliğinin yoğun olduğu ülkeler Türkiye'yi tercih etmektedir. Ancak en bariz etken yaşadıkları ülkelere kıyasla sağlık hizmetin maliyetinin çok düşük olmasıdır. ${ }^{3}$

Tablo 1 verilerine göre 2019 yılına kadar toplam turizm gelirlerindeki artış 2016-2019 y1lına kadar artış göstermiş ancak 2020 yılında pandemi koşullarının da etkisi ile neredeyse üçte bir oranında düşüş yaşanmıştır. Türkiye turizm gelirlerinin artış gösterdiği dönemde sağlik turizmi gelirlerinin aynı seviyede artı̧̧ göstermediği ayrıca tespit edilmiştir. Bunun aksine 2020 y1lında turizm gelirlerinde yaşanan üçte birlik azalış sağlık turizminde yaklaşık \%50 düşüş yaşanmıştır. 
Tablo 1. Türkiye'nin Sağlık Turizmi Gelirleri ve Toplam Turizm Gelirleri İçerisindeki Payı (2015-2020) ${ }^{16,17}$

\begin{tabular}{rrrr}
\hline Yıl & \multicolumn{1}{c}{$\begin{array}{l}\text { Sağlık Turizmi } \\
\text { Geliri (1 000 \$) }\end{array}$} & $\begin{array}{l}\text { Turizm Gelirleri } \\
\text { İçerisindeki Payı (\%) }\end{array}$ & $\begin{array}{l}\text { Turizm Geliri } \\
(\mathbf{1 ~ 0 0 0 ~ \$ ) ~}\end{array}$ \\
\hline 2015 & 794.325 & 2,5 & 31.464 .777 \\
2016 & 904.160 & 4,1 & 22.107 .440 \\
2017 & 1.020 .134 & 3,9 & 26.283 .656 \\
2018 & 1.110 .843 & 3,8 & 29.512 .926 \\
2019 & 1.065 .105 & 3,1 & 34.520 .332 \\
2020 & 548.882 & 4,6 & 12.059 .320 \\
\hline
\end{tabular}

Türkiye'nin sağlık turizmi gelirlerinin Covid 19 pandemisinin etkisindeki 2020 yılı hariç 2017-2019 yıllarında bir miyar doları aşkın bir gelir resmi olarak ifade edilmektedir. Ancak gerçeğin çok daha yüksek olduğu otoritelerce ayrıca belirtilmektedir. Sağlık turizmindeki kayıt dişılık hala tam olarak önlenebilmiş değildir. Kayıt dişı acentelik hizmetleri, hizmetlerin kısmen belgelenmesi, sağlık tesislerinde yaşanan kayıt dışı işlem ve ödemeler gerçek rakamların oluşmasındaki en önemli engellerdir. 2003 yılında uygulamaya konulan "Sağlıkta Dönüşüm Programı" ile büyük kazanımlar elde eden Türkiye, sadece kendi vatandaşlarına sunduğu sağlık hizmeti kalitesini artırmakla kalmayıp dünya vatandaşlarının da tercih ettiği bir sağlık destinasyonu olmuş ve dünyada da bu alanın liderliği yolunda hızla ilerlemektedir.

Dünyada giderek büyüyen sağlık ve termal turizm pastasında Türkiye'nin rekabet gücünün ve payının artırılması amacıyla 2011 y1lında sağlik turizminde mevzuat değişikliği yaşanmıştır. Sağlık Bakanlığı ve bağlı kuruluşların teşkilat ve görevleri hakkında KHK/663 2.10.2011 tarih ve 28103 sayılı Resmî Gazete yayımlanarak Sağlık Hizmetleri Genel Müdürlügü bünyesinde Sağlık Turizmi Daire Başkanlığı'nı kurulmuştur. $\mathrm{Bu}$ daire başkanlığının görevi sağlık turizmi uygulamalarının geliştirilmesine ve iyileştirilmesine yönelik düzenlemeler yaparak yayınlamak, ilgili kurumlarla koordinasyon ve yetkinliği sağlamaktır. ${ }^{18}$ Sağlık Bakanlığının 2019 tarihli resmi yazısına göre Türkiye, uluslararası hasta sayısı bakımından sıralamada dünyanın ilk beş ülkesinden biridir. Ancak, ülkemizde sağlık alanında yapılan reform ve yatırımlar, global sağlik turizmi pastasından daha fazla pay almayı hak etmektedir. Nitekim kamu tarafindan 10.Kalkınma Planı çerçevesinde Sağlık Turizminin Geliştirilmesi Programı deklare edilmiş, bu amaçla çeşitli yapılar kurularak teşvik projeleri geliştirilmiştir. Nihayetinde, 663 sayılı KHK ile bir ilk olarak Türkiye'nin sağlik turizmi hedeflerine ulaşmak için Sağlık Bakanlığg'na bağlı Anonim Şirket olan USHAŞ kurulmuştur.

\section{Sağlık Turizmi Küresel Pazar Eğilimleri}

Günümüzde insanlar gelişmiş iletişim araçları sayesinde farklı ülkelerdeki sağlık sistemine, tıp imkanlarına, kalite ve ekonomi baz alınarak sunulan sağlık hizmetlerine ulaşabilmektedirler. $\mathrm{Bu}$ sayede bilinçlenen hastalar, sağlık paydaşlarını yeni arayışlara ve yapılanmalara yönelmektedirler. $\mathrm{Bu}$ sayede, sağlik turizmi sektörü gün geçtikçe büyümekte ve bu alan bireylerin ilgisi artmaktadır. ${ }^{19}$ Sağlık turizmindeki başarı ve kalkınma ele alındığında dünya genelinde öne çıkan ülkelerin başında Hindistan, Malezya, Tayland, Singapur, Brezilya, Almanya, ABD, Meksika, Güney Afrika ve Kosta Rika gelmektedir. ${ }^{20}$ Geçmişte medikal turizm başta olmak üzere sağlı turizmi algısını gelişmekte olan ülkelerden gelişmiş ülkelere doğru evirmiş iken, bugün gelişmekte olan ülkeler, devletin öncelikli sektörleri arasında sağlık turizmini görmektedir. Bu kapsamda küresel eğilimleri politik, ekonomik, sosyo-kültürel ve teknoloji olarak dört temel tema altında toplanabilir. Söz konusu temalar Tablo 2'de özetlenmiştir. 
Tablo 2. Sağlık Turizminde Küresel Pazar Eğilimleri

\begin{tabular}{|c|c|}
\hline Politik & $\begin{array}{l}\text { 1. Aktif hükümet destekleri } \\
-\quad \text { Standardizasyon ve akreditasyon } \\
\text { - Sağlık vizeleri } \\
\text { - Medikal turizm fuar katılımları } \\
\text { - Devlet teşvikleri (hastane ve klinikler) } \\
\text { 2. Kamu - özel sektör işbirlikleri ile sağlı altyapısının/tesislerin } \\
\text { geliştirilmesi } \\
\text { 3. Üst düzey medikal şehir ve turizm projelerinin artması (Dubai } \\
\text { Healthcare City-BAE, Hainan-Çin benzeri merkezlerin Asya ve } \\
\text { Körfez Bölgesi'nde oluşturulması) }\end{array}$ \\
\hline Ekonomik & $\begin{array}{l}\text { 1. Expedia, Booking.com, TripAdvisor gibi online seyahat } \\
\text { acentelerinin medikal turizm odaklı versiyonları- rezervasyon ve } \\
\text { konsiyerj hizmetleri sağlayan ve komisyon usulüyle çalışan online } \\
\text { medikal acenteler (Quonomedical-Almanya, GetDoc-Malezya, } \\
\text { Practo-Hindistan, Medical Departures-Singapur, Dental } \\
\text { Departures-Tayland) } \\
\text { 2. Hasta deneyiminin geliştirilmesi amacıyla global medikal turizm } \\
\text { acenteleri, lojistik tedarikçileri, oteller, klinik ve hastaneler } \\
\text { arasında sektörler arası iş birlikleri } \\
\text { 3. Sağlık altyapısını geliştirmek amacıyla doğrudan yabancı yatırım } \\
\text { alınması } \\
\text { 4. JCI (ABD), Temos Int (Almanya) benzeri klinik süreçlere global } \\
\text { standartlar getiren ve hasta güvenliğini sağlayan uluslararası } \\
\text { akreditasyon kuruluşlarının artması; klinik ve hastanelerin bunu bir } \\
\text { pazarlama aracı olarak kullanması } \\
\text { 5. Çalışanların sağlı maliyetlerini azaltabilmek adına işverenler } \\
\text { tarafından karşılanan medikal turizm sigortalarının giderek tercih } \\
\text { edilmesi }\end{array}$ \\
\hline Sosyo-kültürel & $\begin{array}{l}\text { 1. Sağlıklı yaşam bilinci yüksek nüfusun özellikle tedavi sonrası } \\
\text { iyileşme süresini destekleyecek, vücut direncini artıracak doğal } \\
\text { içerikler, yöntemler ve geleneksel ilaçlara eğiliminin artması (Çin, } \\
\text { Hindistan, Tayland ve Kore örnekleri) ve sağlı turizmi } \\
\text { destinasyonlarının misafir deneyimine bu boyutları da eklemeleri } \\
\text { 2. Yoğun çalışma koşulları ve insanların kendilerine ayırdıkları } \\
\text { zamanın giderek azalması nedeniyle tatil ve tedavi firsatlarının bir } \\
\text { arada değerlendirilmeye başlanması }\end{array}$ \\
\hline Teknolojik & $\begin{array}{l}\text { 1. Güncel teşhis ve tedavi yöntem ve teknolojilerine yatırım } \\
\text { yapılması (Cyberknife robotik cerrahi vb.) } \\
\text { 2. Global veya bölgesel hastane ve kliniklerin maliyet ve kalite } \\
\text { açısından kıyaslanabilmesine imkan veren web tabanlı ve mobil } \\
\text { aplikasyonlar ve yazılımlar } \\
\text { 3. Giyilebilir cihazlar, mobil-tıp, e-tıp gibi yazılımlar hastalar ve } \\
\text { hizmet sağlayıcılar arasında gerçek zamanlı veri akışı } \\
\text { 4. Tedavi öncesi teşhis ve tedavi sonrası takip ve konsültasyon } \\
\text { süreçlerinde tele-tıp uygulamaları }\end{array}$ \\
\hline
\end{tabular}

\section{Ülkeler Tarafından Sağlık Turizmini Geliştirmek Amacıyla Oluşturulan Organizasyonlar}

Sağlık turizmi alanında küresel rekabet üstünlügü elde etmiş ülkelerin birçoğunda koordinatör kuruluş niteliğinde Bakanlıklara bağlı olarak çeşitli misyonlara sahip organizasyonlar oluşturulmuştur. $\mathrm{Bu}$ bölümde Türkiye, Malezya ve Güney Kore'deki kuruluşlar incelenecektir.

\section{Türkiye}

Kuruluş yılları dikkate alındığında Türkiye, Malezya'dan 10, Güney Kore'den 20 yıl sonra sağlık turizmini geliştirmek amacıyla aktif politika üretmeye başlamıştır.

USHAŞ 2019 yılında kurulmuş ve amacı "Türkiye'nin sağllk hizmetleri potansiyelini keşfedip, geliştirerek sürdürülebilir kllmak"; vizyonunu ise "Türkiye'yi sağllk turizminde dünyanın en başarll markast haline getirmenin yaninda ilaç, tıbbi cihaz ve 
çözüm ortağl olmak" olarak belirlenmiştir.

USHAŞ'a ait detaylı bilgiler Tablo 3 'te

özetlenmiştir. Türkiye USHAŞ'ın

kurulmasıyla küresel sağlık turizmindeki

payının ve rekabet gücünün artırılması

amacıyla sektörün tüm paydaşlarını dikkate alacak şekilde faaliyetlerini yürütmektedir. Kuruluşun vizyonu Türkiye'nin 2023 yılı vizyonuna hizmet edecek şekilde tasarlanmıștır. ${ }^{21}$

\section{Tablo 3. Uluslararası Sağlık Hizmetleri A.Ş. (USHAŞ)}

\section{Görev ve Sorumluluklar}

- Uluslararası sağlı hizmetlerinde aracılık faaliyeti gösteren kurumları yetkilendirmek.

- Sağlık hizmetlerinin uluslararası tanıtımını yapmak, faaliyetleri koordine etmek, yönlendirmek ve desteklemek.

- Uluslararası sağlık hizmetlerine ilişkin aracılık faaliyetlerinde bulunarak, kamu ve özel sektör kuruluşları adına sözl sözleşmelerin yürütülmesine destek sağlamak.

- Uluslararası sağlık hizmetlerinde tarafların karşılaşabilecekleri sorunları tespit ederek önleyici tedbirler almak.

- Ülkemizin sağlık sisteminin tanıtımını yaparak, uluslararası kişi ve kuruluşlara danışmanlık, sistemlerin kurulmas ilişkin yurt dışı talepleri karş̧lamak.

- Yurt dışında sağlık kuruluşu açmak, işletmek, ortaklık kurmak ve iş birliği yapmak, sağlık ve eğitim amacına yönelil ettirmek, ilaç, cihaz ve tıbbî malzeme tedariki yapmak.

- Sağlık meslek eğitimi turizmine yönelik faaliyetlerde bulunmak.

- Ulusal ve uluslararası kongre, seminer ve benzeri etkinliklerde bulunmak, araştırma ve yayın yapmak.

- Uluslararası sağlık hizmetlerine ilişkin politika ve stratejiler, hizmet sunum standartları vb. konularda ilgili kuruluşla Bakanlığa önerilerde bulunmak.

\section{Destekler/Projeler}

- Özel sağlık hizmet sunucularının uluslararası pazar liderliği hedefine ulaşmasını desteklemek.

- Türkiye'nin başta şehir hastaneleri olmak üzere kamu hastanelerinin sağlık turizmi pazarında var olmasını veya gelişm

- Türkiye'nin GETAT, SPA, Wellness, termal, ileri yaş ve engelli turizmi ile turistin sağlığı faaliyetlerinin nitelik geliştirilmesini desteklemek.

- Türkiye'nin ilaç, tıbbi cihaz, sarf ürünlerinin ve firmalarının uluslararası ihracat payının korunması ve artırılmasını des

- Sağlık turizminde, misafir memnuniyeti odaklı, kalite-akreditasyon merkezli, ölçülebilir, izlenebilir, denetlenen ve güvenilir hizmet sunumu için farkındalığı artırmak; bu alanda yapılan faaliyet ve düzenlemeleri destekleyerek geliştirmek.

- Türkiye'nin ilaç, tıbbi cihaz, sarf ürünlerinin ve firmalarının uluslararası ihracat payının korunması ve artırılmasını desteklemek.

- Türkiye'nin sağlık turizmi başta olmak üzere, sağlık yönetim bilgi ve deneyiminin akademik gelişimine katkı sağlamak, uluslararası arenaya taşınmasını desteklemek.

- Sağlık turizmi ile görev sahamıza giren tüm konularda, sağlık diplomasisi faaliyetleri gerçekleştirmek ve ülkemizin bu konudaki politikalarını desteklemek.

- Sağlık meslekleri eğitimi konusunda teşvikler geliştirerek, uluslararası öğrencileri ve eğitim kurumlarını desteklemek.

\section{Tutundurma ve Markalaşma Faaliyetleri}

- Türkiye'nin medikal turizm potansiyelini oluşturan tüm kuruluşlarının, bilinirliğinin ve pazar paylarının artırılmasına yönelik faaliyetler yapılması hedeflenmektedir.

- Tüm sektörün sahipleneceği tek bir Türkiye medikal turizmi çatı markası oluşturulması ve bu markanın tanıtım ürünleri hazırlanması hedeflenmektedir.

- Çatı marka ile tüm sektörü temsil eden sağlık turizmi portalinin aktivasyonu sağlanacak ve sağlık kurumları portale üye yapılacaktır.

- Portalin yurt içi ve yurt dışı tanıtımları yapılarak ziyaretçi ve üye sayıları artırılacaktır.

- Çatı marka için hedef pazarlar danışma kurulu iş birliği ile analiz edilecek ve seçilen hedef pazarlara yönelik sosyal medya hesapları aktif edilecektir.

- Türkiye'nin medikal turizm kapasitesinin tüm medya basamaklarında tanınırlığının arttırılmasına yönelik çalışmalar yapılacaktır.

- Ulusal ve uluslararası tanıtım amaçlı organizasyonlara katılım gerçekleştirilecek ya da USHAŞ tarafından organizasyonlar oluşturulacak ve "HEALTH TURKEY" markası altında Türkiye'nin medikal turizm kapasitesi tanıtılacaktır. 


\section{Malezya}

Malezya sağlık turizminde uzun bir geçmişi olmamasına rağmen her geçen gün konumunu güçlendirerek bu alandaki ilk 10 ülke arasında yerini almıştır. Malezya'da medikal turizm sektörü, Sağlık Bakanlığı'nın yetkisi altındaki MHTC tarafindan kontrol ve organize edilmektedir. ${ }^{22} 2005$ yilında Malezya Sağlık Bakanlığı tarafından kurulmuştur, 2009 yılında Malezya Kabinesinin onayı ile Sağlık Bakanlığı bünyesinde resmi bir kurum statüsü kazanmıştır. 2011 yılında daha fazla esneklik kazanmak için bağımsız yapı haline getirilmiş; özelleştirilmesi sonrasında ise sağlık turisti sayısı ikiye katlanmıştır. MHTC, Sağlık ve Turizm Bakanlıkları, Malezya Sağlıkta Kalite Topluluğu ve Malezya Özel Hastaneler Birliği tarafindan desteklenme ve koordineli bir şekilde faaliyetlerini yürütmektedir. $\mathrm{Bu}$ sayede sektördeki muazzam pozitif yönlü değişikliğin temel aktörü olmuştur. ${ }^{22}$ Sektördeki bu başarı sayesinde International Medical Travel Journal (IMTJ), Malezya'yı 2015 'ten 2017'ye kadar üst üste üç y1l boyunca "Yllın Săgllk ve Medikal Turizm Destinasyonu" ödülüne layık gördü. ${ }^{23}$ Pollard (2012) Malezya'nın bu başarıyı elde etmesinde koordineli çalışmaların yanı sıra sağlık hizmet bakım kalitesi ve standardının artırılmas1, seyahat ve sektör genelinde

Tablo 4. Malezya Sağlık Seyahat Konseyi

Ziyaretçilerin sorunsuz bir sağlık hizmeti deneyimi yaşamalarını sağlamak için ülkenin sağlık hizmetleri seyahat endüstrisinin genel stratejik gelişimini kolaylaştırmayı ve aynı zamanda ülkenin sağlık hizmeti sunumu için küresel profilini yükseltmeyi amaçlamaktadır.

\begin{tabular}{|c|c|}
\hline Vizyon & Malezya’yı önde gelen küresel sağlık hizmetleri destinasyonu yapmak. \\
\hline $\begin{array}{l}\text { Görev ve } \\
\text { Sorumluluklar }\end{array}$ & $\begin{array}{l}\text { - Sağlık turizmi sektöründeki tanıtım, iş geliştirme, regülasyon, networking ve sağlık turizmi } \\
\text { konusundaki araştırmaların yönetimi sağlamak } \\
\text { - Kalite iyileştirme ve standardizasyonun sağlanması ve desteklenmesi } \\
\text { - Sağlık Turizmi Hizmetleri Portal Yönetimi (Lokasyon, tedavi alanı, üye kategorisi } \\
\text { ("ordinary»- «elite») arama imkanı, farkll milliyetlere yönelik videolar ve hasta testimonyallart } \\
\text { paylaşımı, Sağllk kontrolü/checkup up paket satışları) }\end{array}$ \\
\hline \multicolumn{2}{|r|}{$\begin{array}{l}\text { - Malezya sağlık turizmini tanıtıcı faaliyetlere yönelik teşviklerde bulunmak } \\
\text { - Sağlı turizmi altyapısını geliştirici yatırımlar çerçevesinde miktarın \%100'üne kadar } \\
\text { gelir vergisi muafiyeti } \\
\text { - MHTC'ye üye diş klinikleri ve ambulans hizmetlerinin akreditasyon masraflarına yönelik } \\
\text { çifte vergi indirim teşvikleri }\end{array}$} \\
\hline $\begin{array}{l}\text { Tutundurma ve } \\
\text { Faaliyetleri }\end{array}$ & $\begin{array}{l}\text { Maı - Çağrı Merkezi Hizmeti: Tüm potansiyel hasta adayları ve hastalar tarafindan ulaşılabilir. } \\
\text { Hastaları tedavi, ulaşım, konaklama, gezi, tedavi imkanları vb. alanlarda bilgilendirir ve } \\
\text { bağımsızlık ilkesi ile hareket eder. }\end{array}$ \\
\hline
\end{tabular}


Tablo 4. (Devamı) Malezya Sağlık Seyahat Konseyi

- Malezya Sağllk Ofisleri: Vietnam, Myanmar ve Endonezya'da uluslararası irtibat ofisleri ișletmektedir.

- INSIGHT: Her sene sağlık turizm sektörü pazar bilgi ve araştırma konferansı düzenleyerek, gelecek senenin planlarının tartışıldığ 1 bir platform oluşturur. $\mathrm{Bu}$ toplantılara ilgili paydaşların üst düzey yönetici ve temsilcileri katılırlar.

- Medya Ödülleri: Her sene Malezya Sağlık Turizmi konusunda makale yazan gazetecilere yönelik ödül töreni düzenlemektedir.

- e-Visa: Hastalara Malezya Göçmen Departmanı ile olan vize sürecinde destek ve yardımcı olmak için kurulan sistemdir.

- Medical Travel Companions ile İşbirliği: MTC şirketi üzerinden ihtiyacı olan hastalara baştan sona bakıc1, hemşire ve paramedik hizmetlerin sunulması

- \#MyLovesYou ve \#ShareMyLove: Malezya'nın konukseverliğinin ve sağlık konusunda önde gelen bir ülke olduğunun tanıtımını yapma amaçlı bir sanat projesi ve seminer etkinliğidir.

- MHTC Karşılama ve Lounge Hizmetleri (Kuala Lumpur Havalimanı): İlgili personel sağlık turistini karşılayarak pasaport kontrol süreçlerini rahat bir şekilde geçmesini sağlamanın yanı sıra Lounge'a uğrayan uluslararası yolculara da Malezya sağlık turizm sektörü ve Malezya Sağlık Ofisleri hakkında bilgi vermektedir.

\section{Güney Kore}

Dünyanın önemli sağlı turizm merkezlerinden biri olan Güney Kore sağlık hizmetlerindeki güçlü altyapısı ve yüksek doktor kalite ve yetkinliği ile ön plana çıkmaktadır.

1999 yılında kurulan KHIDI, hem Güney Kore'nin yerel sağlik endüstrisini geliştirmek hem de küresel medikal turizm sektöründeki rekabet gücünü güçlendirmek için tasarlanmış profesyonel destek programları sunan hükümete bağlı bir kuruluștur. ${ }^{28}$

KHIDI, kuruluşundan bu yana Güney Kore'nin sağlik hizmetleri endüstrisindeki sağlık ve Ar-Ge yatırımlarının genişlemesine önderlik ederek, Asya'nın lider sağlık hizmeti sağlayıcısını, hükümet tarafından denetlenen güvenilir, yüksek kaliteli tıbbi hizmetler sunan bir ülke haline getirmiştir. KHIDI, hastalara tıbbi seyahatle ilgili kapsamlı ve güvenilir bilgiler sağlamayı taahhüt eden tıp, etik, sigorta ve hukuk konularını kapsayan 40 profesyonelden oluşan bir grup olan Medikal Kore kolu aracılığıyla Güney Kore'de medikal turizm hizmetlerini teşvik etmektedir. Denizaşırı hastalara sunulan hizmetler arasinda kanser tedavisi, ortopedik cerrahi ve romatoloji, organ nakli, kalp ve damar cerrahisi, omurga cerrahisi, oftalmoloji, diş hekimliği, Kore geleneksel tıbb1, kozmetik ve plastik cerrahi, kısırlık tedavisi ve KBB bulunmaktadır. Bunlara ek olarak Güney Kore sağlık hizmetlerini yurtdışında tanıtmak ve Kore Sağlık Endüstrisinin denizaşırı genişlemesini kolaylaştırmak için altı Küresel İşletme Ofisi kurmuştur. Bunlar, KHIDI-ABD, KHIDISingapur, KHIDI-Çin, KHIDI-İngiltere, KHIDI-BAE ve KHIDI -Kazakistan'dır. ${ }^{29}$ KHIDI'nın amaç, vizyon ve diğer bilgileri Tablo 4'te özetlenmiştir.

Tablo 5. Kore Sağlık Endüstrisi Geliştirme Enstitüsü (KHIDI)

\begin{tabular}{ll}
\hline Amaç & $\begin{array}{l}\text { Kapsamlı ve profesyonel destek programları sağlayarak ulusal sağlık sektörünü } \\
\text { geliştirmek ve rekabet gücünü artırmak }\end{array}$ \\
\hline Vizyon & Sağlık alanında Güney Kore'nin global mevcudiyetini artırarak ülkeyi “Asya'nın \\
& sağlık hizmetleri merkezi” haline getirmek. \\
\hline & - Sağlık hizmetlerinin bilinirliği ve algısını yurt dışı pazarlama faaliyetleri ile \\
& geliştirmek, pazar araştırmaları yürütmek, hastanelerin yurt dişı yatırımlarına \\
& destek olmak (lisans alma, vb.) \\
Görev ve & - Sağlık sektörü gelişim planı ve politikalar oluşturulmak \\
Sorumluluklar & - Sağlık politika ve trendlerini analizini yapmak \\
& - Sağlık sektörü çapında entegre istatiksel veri tabanı kurmak \\
& - Sağlık sektöründe bilgi paylaşım sistemi kurmak
\end{tabular}




\begin{tabular}{|c|c|}
\hline $\begin{array}{l}\text { Görev ve } \\
\text { Sorumluluklar }\end{array}$ & $\begin{array}{l}\text { - Start-up finansmanı sağlamak } \\
\text { - Ar-Ge destek ve danışmanlığı vermek } \\
\text { - Hasta ve sağlık kuruluşu anlaşmazlıkların takibi ve şikayet bildiriminde bulunmak. }\end{array}$ \\
\hline Destekler/Projeler & $\begin{array}{l}\text { Güney Kore hastanelerin global inisiyatiflerini desteklemek amacıyla her sene proje } \\
\text { planları toplanmakta, değerlendirilmekte, fizibilite çalışmaları gerçekleştirilerek her } \\
\text { projeye 28-93.000 USD arasında hibe sağlanmaktadır. } \\
\text { - BIO-HEALTH Teknolojisini Ticarileştirme Desteği } \\
\text { - BIO-HEALTH Sertifikasyonu ve Danışmanlığı } \\
\text { - BIO-HEALTH Global Pazarlama } \\
\text { - Hastane Kapasiteleri ve Rekabet Gücü } \\
\text { - BIO-HEALTH Uzmanlarının Eğitim }\end{array}$ \\
\hline $\begin{array}{l}\text { Tutundurma ve } \\
\text { Markalaşma } \\
\text { Faaliyetleri }\end{array}$ & $\begin{array}{l}\text { - Az Gelişmiş Ülkelerde Filantropi Uygulamaları } \\
\text { - Yabancı Doktorların Eğitim Programlarına Davet Edilmesi } \\
\text { - Sağlık Kuruluşları ve Aracı Kurumlara Tek Noktadan Erişim İmkanı } \\
\text { - Medical Packages Korea websitesi: } \\
\text { - İngilizce, Japonca, Çince ve Rusça dil seçenekleri bulunmaktadır. } \\
\text { - Sağlık kuruluşu paket fiyat bilgileri şeffaf olarak paylaşılmaktadır. } \\
\text { - Sağlık Bakanlığı'na kayıtlı } 127 \text { s } 38 \text { hastane ve } 1299 \text { sağlık paketine siteden erişim } \\
\text { - Paketlenebilir ürünler/hizmet alanları (check up, dermatoloji ve kozmetik, "Korean } \\
\text { Medicine”, diş, ortopedi, göz, IVF ve jinekoloji, Kardiyotorasik cerrahi, ENT, } \\
\text { Üroloji ve Gastroenteroloji) oluşturulmuştur. } \\
\text { - Visit Medical Korea web sitesi: } \\
\text { - Bu site üzerinden medikal hizmetlerin yanı sıra wellness, konaklama, tur, destek } \\
\text { (Sağlık Turizm Bilgi Merkezi, Şikayet Yönetim Merkezi, Sağlık Vizesi, Estetik } \\
\text { Operasyonlar Vergi İadesi) hizmetleri arama seçenekleri de sağlanmaktadır. } \\
\text { - In transit yolculara yönelik havaalanı civarındaki kuruluşlarla sağlık turizmi } \\
\text { paketleri oluşturmuştur. } \\
\text { - Hasta ve yakınlarına yönelik hastanelere özel ya da karma turlar sunulmaktadır. }\end{array}$ \\
\hline
\end{tabular}

\section{SONUÇ VE ÖNERILER}

Sağlık turizmi, medikal turizm, GETAT, SPA, Wellness, termal, ileri yaş ve engelli turizmi ile turistin sağlığı faaliyetlerinin tümü birbirini destekler niteliktedir. Türkiye son 10 yılda özel sektörün liderliğinde medikal turizm başlığında önemli başarılar ortaya koymuştur. Devletin çeşitli başlıklarda destekleriyle medikal turizmde elde edilen başarının geliştirilmesi ve diğer sağlık turizmi kollarında da benzer başarının sergilenmesi amaciyla kurulan USHAŞ diğer ülke örnekleriyle de rekabet ve iş birliğini beraber yürütmeli ve başarılı uygulamaları ülkemizde de hayata geçirmelidir. Kuruluş y1llarına göre değerlendirmek gerekirse Ülkemiz, Malezya'dan 10, Güney Kore'den 20 yıl sonra kurumlarını oluşturmaya başlamıştır. USHAŞ daha birinci yılında Covid-19 Pandemisi ile karşılaşmış, bu süreçte de koruyucu ekipman tedarikini başarıyla yürütmüştür. Pandemi sürecinin Türkiye'de iyi yönetilmesi, sağlık hizmeti algısına olumlu katkı sağlaması beklenmektedir.
Türkiye'nin başta medikal turizm olmak üzere tüm sağlık turizmi başlıklarında potansiyelini geliştirmek üzere stratejik plan ve pazarlama planı oluşturulmuştur. Esas lokomotif gücü oluşturan özel sağlık sektörü ve acentelerin etkili desteklenmesi pazar liderliği hedefine ulaştırabilecektir. USHAŞ ile alanlarında en başarılı kurumlar ile yapılan karşılaştırma sonucunda Türkiye için öneriler aşağıdaki gibi sıralanabilir:

- Sağlık sektörünün tüm paydaşları ile koordineli bir süreç yönetiminin yürütülmesi,

- Uluslararası geçerliliği olan mevzuat çalışmalarının yapılması,

- Farklı pazarlar için odaklanmış pazarlama stratejilerinin geliştirilmesi,

- Sağlık turizmi hizmetlerini kapsayacak şekilde platform geliştirilmesi ve efektif kullanımının sağlanması,

- Uluslararası örgütlenmeler ve yut dışında kurulacak irtibat ofisleri ile tanitım faaliyetlerinin daha aktif bir şekilde yürütülmesi, 
- Sağlık turizminin tanıtılmasında diğer turizm alanlarında da faaliyetlerin yürütülmesi,

- Alanla ilgili projelerin teşvik edilmesi ve maddi olarak desteklenmesi,

- Sağlık turizmi alanında yayımlanan makale ve haberlerin desteklenmesi amaciyla medya ödüllerinin verilmesi,

- Farklı dillerde ve efektif kullanıma sahip tedavi süreçleri hakkında kapsamlı bilgilerin erişime açık olacağı internet sitelerinin oluşturulması,

- Yabancı uyruklu sağlık profesyonellerinin eğitim faaliyetlerine katılımının sağlanmasıdır.

\section{KAYNAKLAR}

1. Bookman M.Z, Bookman, K.R. (2007). Medical Tourism in Developing Countries. New York: Palgrave Macmillan.

2. Anne Jenner, E. (2008). Unsettled Borders of Care: Medical Tourism as a New Dimension In America's Health Care Crisis. In: Jocabs Kronenfeld (Ed.) Care for Major Health Problems and Population Health Concerns (pp.235-249)

3. Tontuş, H.Ö. (2019). "Dünyada Sağlık Turizmi”. Ankara: SATURK.

4. Ağaoğlu, F.O, Karagöz, N. ve Zabun S. (2019). "Sağlık Turizmi Uygulamaları ve Türkiye'ye Getirilerini İlişkin Bir Değerlendirme". Cumhuriyet Üniversitesi İ̈BF Dergisi, 20 (2), 428-450.

5. Dökme, S. (2019). "Medikal Turizmde Hasta Tercihini Etkileyen Faktörler". Social Sciences Studies Journal, 5 (30), 825-831.

6. Mert, G. (2013). "Sağlık Turizmi ve Uygulanabilirliğii". IAAOJ Social Science, 1(1):103-126.

7. Özsarı, S.H, Karatana, Ö. (2013). "Sağlık Turizmi Açısından Türkiye'nin Durumu." J Kartal Train Res Hosp, 24 (2).

8. Barca, M, Akdeve, E. ve Gedik Balay, İ. (2013). "Türkiye Sağlık Turizm Sektörünün Analizi ve Strateji Önerileri”. İşletme Araştırmaları Dergisi. 5 (3), 64-92.

9. Büyüközkan G, Mukul E, Kongar, E. (2020). "Health Tourism Strategy Selection Via SWOT Analysis and Integrated Hesitant Fuzzy Linguistic AHP-MABAC Approach". Socio-Economic Planning Sciences, 74, 1-14

10. İçöz, O. (2009). "Sağlık Turizmi Kapsamında Medikal (Tıbbi) Turizm ve Türkiye'nin Olanakları". Journal of Yasar University, 4 (14), 2257-2279.

11. Kilıçarslan, M. (2019). "SWOT Analysis of Health Tourism in Turkey". Elektronik Sosyal Bilimler Dergisi, 18(71), 135-1145.

12. Kördeve, M.K. (2018). "Hastanelerde Stratejik Yönetim SWOT Analizi: Özel Bir Hastane Uygulaması". Sağlık Yönetimi Dergisi, 2 (1), 67-78.

13. Kostak, D. (2007). "Turizm hareketleri (Türkiye örneği üzerinden sağlı turizmi)" (Yüksek Lisans Tezi) Marmara Üniversitesi Sosyal Bilimler Enstitüsü, İstanbul.

14. Omay, E.G.G. ve Cengiz, E. (2013). "Health Tourism in Turkey: Opportunities and Threats". Mediterrian Journal of Social Sciences, 4 (10), 424-431.

15. SATURK. (2020). Erişim adresi: http://www.saturk.gov. tr/images/pdf/hst/turkiyesagliginmerkezi.pdf (Erișim tarihi: 03.03.2021).
16. Kültür ve Turizm Bakanlığı. (2020). 2019 Y1lı Konaklama İstatistikleri Yıllık Bülteni. Ankara: Kültür ve Turizm Bakanlığı.

17. TÜİK. (2021). İstatistik Veri Portalı. Published 2020. Erişim adresi:https://data.tuik.gov.tr/Kategori/GetKate gori?p=saglik-ve-sosyal-koruma-101\&dil=1 (Erişim tarihi: 31.03.2021)

18. Özer, Ö. ve Sonğur, C. (2012). “Türkiye'nin Dünya Sağlık Turizmindeki Yeri ve Ekonomik Boyutu". Mehmet Akif Ersoy Üniversitesi Sosyal Bilimler Enstitüsü Dergisi, 4 (7), 69-81.

19. Aydın, D. (2014). "Türkiye Sağlık Turizmi Cep Kitabı”. Ankara: Visit Turkey for Healthcare Platformu.

20. Soysal, A. (2017). "Sağlik Turizmi: Tehdit ve Fırsatlar Bağlamında Türkiye Açısından Bir Durum Değerlendirmesi”, Uluslararası Turizm ve Sosyal Araştırmalar Dergisi, (2), 169-188.

21. USHAS. (2021). 2021-2024 Stratejik Plan. İstanbul: Uluslararası Sağlık Hizmetleri Anonim Şirketi.

22. Christian, O.C, Stanley, N, Imoudu, E.W. and Hadina, H. (2019). "Promoting Malysia Medical Tourism Through MyCrest Oriented Retrofitted Hospitals". Journal of Social Sciences and Humanities. 16 (8), 1-12.

23. MHTC. (2018). Malaysia to Generate Healthcare Revenue RM2.8b Malaysia Health Tourism Council.

24. Pollard, K. (2012). Medical tourism: Key facts How many UK medical tourists are there?. Erişim adresi: www.treatmentabroad.com, (Erişim tarihi: 03.31.2021)

25. Bona-idollo, K. ve Abdullah, M. (2020). "The future challenges of the Malaysian health care system in medical tourism" Journal of Tourism Studies and Hospitality Researches. 1 (1), 101-108.

26. Alserhan, B.A. and Alserhan, Z.A. (2012). "Researching Muslim Consumers: Do They Represent the FourthBillion Consumer Segment?" Journal of Islamic Marketing. 3 (2), 121-138.

27. Rahman, M.K, Zailani, S. and Musa, G. (2017). "Tapping into the Emerging Muslim-friendly Medical Tourism Market: Evidence From Malaysia”. Journal of Islamic Marketing, 8 (4), 514-532.

28. Seo, B.R. and Park, S.H. (2008) "Policies to Promote Medical Tourism in Korea: A Narrative Review" Iran J Public Health. 47 (8), 1077-1083.

29. KHIDI. (2020). Korea Health Industry Development Institute (KHIDI). International Medical Travel Journal. Published 2020. Erişim adresi: https://www.imtj.com/ organisation-details/korea-health-industry-developmentinstitute-khidi-4265/ (Erişim tarihi: 03.31.2021). 